http://ejournal.sumselprov.go.id

\title{
PENGARUH PEMBERIAN PUDING D'BINGU TERHADAP PENURUNAN KADAR GLUKOSA DARAH PADA PENDERITA DM TIPE 2 RAWAT JALAN DI PUSKESMAS SOSIAL PALEMBANG
}

\author{
THE IMPACT OF D'BINGU PUDDING TO DECREASE BLOOD GLUCOSE \\ LEVEL ON TYPE 2 OF DM PATIENT AT SOSIAL PUBLIC HEALTH \\ CENTER PALEMBANG
}

\author{
Rhea Ajeng Gipyapuri*, Susyani, Terati \\ Jurusan Gizi, Politeknik Kementerian Kesehatan Palembang \\ * Korespodensi Penulis : suzie.ani78@gmail.com;
}

\begin{abstract}
Diabetes Mellitus is a diseases metabolic characterized by hiperglikemia as a result of septal secrection of insulin, work insulin or both. It's caused by unbalance intake of food that raising blood glucose levels. Low glycemic index and high fiber snacks are needed by the DM patient. The purpose is to identify the effect of d'bingu pudding in decreasing blood glucose level on DM outpatient type 2 at Sosial Public Health Center. The research type is quantitative research with quasi experiment design by using paired t-test and t-independen data analysis. The result is most of the action group have a low average of intake, which energy intake is 50\%, carbohydrate intake is $50 \%$, and fiber is $66.7 \%$. The control group results are $53.3 \%$ of energy intake, $60 \%$ of carbohydrate intake, and $46.7 \%$ of fiber intake. The blood glucose difference for the action group is p-value 0.0000, and for the control group is p-value 0.011. The distribution of d'bingu pudding in decreasing of blood glucose level with p-value 0.000. The conclusion of this research is d'bingu pudding decrease the blood glucose on type 2 DM patient in Palembang social health center.
\end{abstract}

Keywords: Diabetes Mellitus; blood glucose level; D’bingu pudding

\begin{abstract}
ABSTRAK
Diabetes Mellitus merupakan penyakit metabolik yang ditandai dengan hiperglikemia sebagai akibat dari defek sekresi insulin, kerja insulin atau keduanya. Diabetes Mellitus disebabkan karena tidak seimbangnya asupan makanan sehingga meningkatkan kadar glukosa darah. Makanan camilan dengan indeks glikemik rendah dan tinggi serat dibutuhkan untuk penderita DM. Tujuan penelitian ini yaitu untuk mengetahui pengaruh pemberian puding d'bingu terhadap penurunan kadar glukosa darah pada penderita DM di Puskesmas Sosial Palembang. Jenis penelitian ini adalah penelitian kuantitatif dengan desain quasi eksperiment. Analisa data ini menggunakan paired $t$-test dan t-independen.Hasil penelitian menyatakan sebagian besar kelompok perlakuan rata-rata asupannya kurang yaitu asupan energi $50 \%$, karbohidrat 50\% dan serat cukup 66.7\%. Sedangkan pada kelompok kontrol asupan energi $53.3 \%$, karbohidrat $60 \%$, dan serat $46,7 \%$. Rata-rata kadar glukosa darah sebelum pada kelompok perlakuan $275.17 \mathrm{mg} / \mathrm{dl}$ dan kelompok kontrol 263.77 mg/dl sedangkan rata-rata kadar glukosa darah setelah pada kelompok perlakuan $221.87 \mathrm{mg} / \mathrm{dl}$ dan kelompok kontrol $250.03 \mathrm{mg} / \mathrm{dl}$. Perbedaan kadar glukosa darah sebelum dan setelah kelompok perlakuan yaitu $p$-value 0.000 dan kelompok kontrol yaitu $p$-value 0.011 . Ada pengaruh pemberian puding d'bingu terhadap penurunan kadar glukosa darah dengan $p$-value 0.000 . Kesimpulan yang didapat adalah puding D’bingu dapat menurunkan kadar glukosa darah pada penderita DM Tipe 2 di Puskesmas Sosial Palembang. Kata Kunci : Diabetes mellitus; Kadar glukosa darah; Puding D’bingu.
\end{abstract}




\section{PENDAHULUAN}

Diabetes melitus adalah penyakit metabolisme yang merupakan suatu kumpulan gejala yang timbul pada seseorang karena adanya peningkatan kadar glukosa darah di atas nilai normal. Penyakit ini disebabkan gangguan metabolisme glukosa akibat kekurangan insulin baik secara absolut maupun relatif (Kesehatan 2013).

Menurut International Diabetes Federation (IDF) tahun 2013 (Beckman 2013), Indonesia menempati urutan ke 5 di dunia dengan jumlah penderita diabetes sebanyak 8,5 juta jiwa. Dan angka kejadian diabetes di Indonesia mengalami peningkatan dari $1,1 \%$ tahun 2007 menjadi $2,1 \%$ pada tahun 2013 dan diperkirakan mencapai 21,3 juta jiwa penderita pada tahun 2030 (Kesehatan 2013).

Data dari profil kesehatan Provinsi Sumatera Selatan tahun 2010, prevalensi penyakit diabetes mellitus tertinggi berada di Kota Palembang sebesar 22,79\% dibandingkan dengan Kabupaten/Kota lainnya di Provinsi Sumatera Selatan. Dari data Dinkes Sumatera Selatan penderita diabetes pada tahun 2014 mencapai 17.541 penderita, dan pada tahun 2015 mengalami peningkatan menjadi 22.042 penderita. Berdasarkan data yang telah didapatkan jumlah kasus baru penderita penyakit diabetes mellitus di Kota Palembang pada tahun 2017 sebanyak 4.823, sedangkan di Puskesmas sosial berjumlah 180 penderita dengan prevalensi $3,7 \%$.

Peranan serat sangat penting bagi penderita diabetes, karena serat mampu menyerap air dan mengikat glukosa, sehingga dapat mengurangi ketersediaan karbohidrat. Diet cukup serat dapat menyebabkan terjadinya kompleks karbohidrat dan serat, sehingga daya cerna karbohidrat berkurang. Keadaan tersebut mampu meredam kenaikan glukosa darah dan menjadikannya tetap terkontrol (Santoso 2011).

Ubi ungu memiliki serat pangan yang baik untuk pencernaan dan kandungan antioksidan seperti antosianin (Isnaini 2018). Sedangkan kacang kedelai memiliki komponen yang memberikan efek hipoglikemik yaitu kandungan protein, isoflavon, serat, lesitin, serta rendahnya indeks glikemik (Sinaga and Wirawanni 2012) (Ginting, Utomo, and Yulifianti 2015)

Penelitian ini bertujuan untuk mengetahui pengaruh pemberian puding d'bingu (puding ubi ungu) terhadap penurunan kadar glukosa darah pada penderita DM di Puskesmas Sosial Palembang.

\section{METODE PENELITIAN}

Penelitian ini bersifat eksperiment semu dengan rancangan pretest and posttest with control group. Variabel bebas dalam penelitian ini adalah pemberian puding d'bingu (100 gram ubi ungu \& $100 \mathrm{ml}$ susu kedelai), dan varibel terikat adalah kadar glukosa darah.

Subjek penelitian ini adalah penderita diabetes mellitus tipe 2 yang berada di wilayah kerja Puskesmas Sosial Palembang. Penelitian dilakukan pada bulan Januari April 2019. Kriteria inklusi penelitian ini adalah berusia $\geq 40$ tahun, kadar glukosa darah $\geq 200 \mathrm{mg} / \mathrm{dl}$, dan mengonsumsi obat tetapi tidak tergantung dengan insulin.

Penentuan responden dilakukan dengan metode simple random sampling. Jumlah responden masing-masing 30 untuk tiap kelompok. Kelompok perlakuan mendapatkan puding d'bingu sebanyak 4 cup selama 3 hari berturut-turut dan mengonsumsi obat, sedangkan kelompok kontrol tidak mendapatkan perlakuan dan hanya mengonsumsi obat.

Kadar glukosa darah diukur sebelum dilakukan intervensi menggunakan alat glukometer kemudian diukur kembali setelah diberikan intervensi selama 3 hari. data status gizi didapatkan menggunakan pengukuran antropometri dan form recall, sedangkan data karakteristik responden didapatkan menggunakan formulir identitas responden dengan wawancara langsung.

Karakteristik responden dianalisis menggunakan analisis deskriptif. Perbedaan kadar glukosa darah sebelum dan setelah intervensi kedua kelompok di uji dengan paired sample t-test. Perbedaan pengaruh perlakuan kedua kelompok dianalisis menggunakan uji independent t-test. 


\section{HASIL DAN PEMBAHASAN}

\section{Hasil}

\section{Karakteristik Responden}

Karakteristik responden terdiri dari usia, jenis kelamin dan IMT disajikan dalam tabel 1.

Tabel 1. Karakteristik Responden

\begin{tabular}{lcccc}
\hline \multicolumn{1}{c}{$\begin{array}{c}\text { Karakteristik } \\
\text { Responden }\end{array}$} & \multicolumn{2}{c}{ Perlakuan } & \multicolumn{2}{c}{ Kontrol } \\
\cline { 2 - 5 } & $\mathrm{n}$ & $\mathbf{\%}$ & $\mathrm{n}$ & $\mathbf{\%}$ \\
\hline Usia & & & & \\
$45-59$ tahun & 17 & 56.7 & 20 & 66.7 \\
$60-69$ tahun & 12 & 40 & 9 & 30 \\
$\geq 70$ tahun & 1 & 3.3 & 1 & 3 \\
\hline Jenis Kelamin & & & & \\
Laki - laki & 9 & 30 & 8 & 26.7 \\
Perempuan & 21 & 70 & 22 & 73.3 \\
\hline IMT & 19 & 63.3 & 11 & 36.7 \\
Normal & 5 & 16.7 & 8 & 26.7 \\
Overweight & 6 & 20 & 11 & 36.7 \\
Obesitas & & & &
\end{tabular}

Rata-rata asupan zat gizi, serat dan kadar glukosa darah

Rata-rata asupan zat gizi dan serat disajikan dalam tabel 2. Rata - rata kadar glukosa darah disajikan dalam tabel 3.

Tabel 2. Rata - rata Asupan Zat Gizi dan Serat

\begin{tabular}{lcccc}
\hline \multicolumn{1}{c}{ Karakteristik } & \multicolumn{2}{c}{ Perlakuan } & \multicolumn{2}{c}{ Kontrol } \\
\cline { 2 - 5 } Energi & $\mathrm{N}$ & $\%$ & $\mathrm{n}$ & $\%$ \\
Lebih & & & & \\
Cukup & 6 & 20 & 7 & 23,3 \\
Kurang & 9 & 30 & 7 & 23,3 \\
\hline Protein & 15 & 50 & 16 & 53,3 \\
Lebih & & & & \\
Cukup & 12 & 40 & 10 & 33,3 \\
Kurang & 4 & 13,3 & 4 & 13,3 \\
\hline Lemak & 14 & 46,7 & 16 & 53,3 \\
Lebih & & & & \\
Cukup & 3 & 10 & 2 & 6,7 \\
Kurang & 0 & 0 & 7 & 23,3 \\
\hline Karbohidrat & 27 & 90 & 21 & 70 \\
Lebih & & & & \\
Cukup & 4 & 13,3 & 6 & 20 \\
Kurang & 11 & 36,7 & 6 & 20 \\
\hline Serat & 15 & 50 & 18 & 60 \\
Cukup & & & & \\
Kurang & 20 & 66,7 & 14 & 46,7 \\
\hline & 10 & 33,3 & 16 & 53,3 \\
\hline
\end{tabular}

Tabel 3. Rata - rata Glukosa Darah

\begin{tabular}{lccc}
\hline \multirow{2}{*}{ Kelompok } & \multicolumn{3}{c}{ Glukosa Darah } \\
\cline { 2 - 4 } & Tertinggi & Terendah & $\begin{array}{c}\text { Rata- } \\
\text { rata }\end{array}$ \\
\hline $\begin{array}{l}\text { Sebelum } \\
\text { Perlakuan }\end{array}$ & 498 & 207 & 275.17 \\
Kontrol & 333 & 210 & 263.77 \\
\hline Setelah & & & \\
Perlakuan & 388 & 116 & 221.87 \\
Kontrol & 303 & 189 & 250.03 \\
\hline
\end{tabular}

Perbedaan rata - rata kadar glukosa darah sebelum dan setelah

Rata - rata kadar glukosa darah sebelum dan setelah intervensi disajikan dalam tabel 4.

Tabel 4. Perbedaan Glukosa Darah Sebelum dan Setelah Perlakuan

\begin{tabular}{lccc}
\hline \multirow{2}{*}{ Kelompok } & Mean & Mean & \\
& Awal \pm SD & Akhir \pm & P \\
& SD & \\
\hline Perlakuan & $275.17 \pm$ & $221.87 \pm$ & 0.000 \\
& 62.04 & 64.42 & \\
Pembanding & $263.77 \pm$ & $250.03 \pm$ & 0.011 \\
& 38.35 & 28.58 & \\
& & & \\
\hline
\end{tabular}

Pengaruh Pemberian Puding D'bingu Terhadap Penurunan Kadar Glukosa Darah

Pengaruh pemberian puding d'bingu terhadap penurunan kadar glukosa darah disajikan dalam Tabel 5.

Tabel 5. Pengaruh Pemberian Puding D'bingu Terhadap Penurunan Kadar Glukosa Darah

\begin{tabular}{|c|c|c|c|}
\hline Kelompok & $\begin{array}{c}\text { Mean Selisih } \\
\pm \text { SD }\end{array}$ & $\mathrm{t}$ & $\mathrm{p}$ \\
\hline Perlakuan & $\begin{array}{c}53.30 \pm \\
49.796\end{array}$ & 3.801 & 0.000 \\
\hline Pembanding & $\begin{array}{l}13.73 \pm \\
27.775\end{array}$ & 3.801 & \\
\hline
\end{tabular}

\section{Pembahasan}

Berdasarkan tabel 1. karakteristik responden dalam penelitian ini sebagian besar berusia $45-59$ tahun dengan jenis kelamin perempuan dan status gizi normal. Penelitian ini membuktikan bahwa faktor usia mempengaruhi penurunan pada semua sistem tubuh, tidak terkecuali sistem endokrin. Hal ini sejalan dengan penelitian Isnaini, Nur, Ratnasari bahwa Penambahan usia menyebabkan resistensi insulin yang 
mengakibatkan tidak stabilnya kadar gula darah sehingga banyaknya kejadian diabetes mellitus salah satu diantaranya adalah karena faktor penambahan usia yang secara degenerative menyebabkan penurunan fungsi tubuh (Isnaini2018).

Penelitian ini juga memiliki kesamaan dari penelitian sebelumnya yang menyatakan bahwa perempuan memang memiliki kecenderungan mengonsumsi makanan jajanan seperti coklat, gula dan makanan cepat saji yang menyebabkan meningkatnya kadar glukosa darah akibat pola makan yang tidak baik (Sudaryanto, Setiyadi, and Frankilawati 2014), sehingga memiliki peluang peningkatan indeks massa tubuh yang lebih besar (Fatimah 2015). Menurut (Wicaksono 2011), orang dengan status gizi overweight memiliki resiko 2 kali terjadinya DM Tipe 2 dibandingkan dengan orang dengan status gizi normal meskipun secara statistik tidak bermakna.

Berdasarkan Tabel 2. Rata-rata asupan energi, protein, lemak dan karbohidrat pada tiap kelompok masih tergolong kurang. Pada pasien diabetes mellitus tidak dianjurkan asupan energy lebih ataupun kurang dari kebutuhan, karena pada saat asupan energy kurang dapat terjadi hipoglikemia (Soelistijo et al. 2015), yang akan menyebabkan kerusakan otak yang permanen, dan dapat menyebabkan koma hingga kematian (Kedia 2011): Begitupun protein, apabila asupan protein tidak baik maka kondisi tubuh akan terganggu, karena fungsi protein juga sebagai pengatur kelangsungan proses di dalam tubuh dan sebagai pemberi tenaga dalam keadaan energy kurang tercukupi oleh karbohidrat dan lemak (Karta 2000).

Konsumsi lemak yang berlebihan pada penderita diabetes mellitus akan menyebabkan terjadinya komplikasi penyakit seperti kardiovaskuler. Penderita diabetes mellitus lebih sensitive terhadap kolesterol dibandingkan yang tidak menderita penyakit diabetes mellitus. Asupan makanan merupakan faktor risiko yang dapat menyebabkan diabetes mellitus salah satunya ialah asupan karbohidrat. Konsumsi karbohidrat yang berlebihan akan menyebabkan lebih banyak gula di dalam tubuh. Pada penderita diabetes mellitus tipe 2 jaringan tubuh tidak mampu menyimpan dan menggunakan gula, sehingga kadar gula darah dipengaruhi oleh tingginya asupan karbohidrat yang dimakan (Paruntu 2012).

Asupan serat pada kelompok perlakuan tergolong cukup, namun pada kelompok control masih kurang. Menurut (Muliani 2013), serat dapat membantu penyerapan glukosa dan memperlambat pelepasan glukosa di dalam darah. Kandungan serat yang tinggi dalam makanan akan mempunyai indeks glikemik yang rendah sehingga dapat memperpanjang pengosongan lambung yang dapat menurunkan sekresi insulin dan kolesterol total dalam tubuh (Herliyanti 2016).

Berdasarkan tabel 4. Hasil uji statistik ( $\mathrm{t}$ dependen) didapatkan pada kelompok perlakuan nilai $\mathrm{p}=0.000$ dan pada kelompok pembanding nilai $\mathrm{p}=0.011$ yang berarti $\mathrm{p}$-value kedua kelompok sama-sama $<0.05$ sehingga dapat disimpulkan bahwa ada pengaruh penurunan kadar glukosa darah pada kelompok perlakuan yang diberi pudding d'bingu dan pada kelompok pembanding yang tidak diberi pudding d'bingu tetapi masih tetap mengonsumsi obat penurun kadar glukosa darah.

Adanya pengaruh penurunan kadar glukosa darah pada kelompok perlakuan ini sejalan dengan penelitian yang dilakukan oleh Suda, et al. 2003 dalam (Ginting, Utomo, and Yulifianti 2015), yang menunjukkan bahwa pemberian maltosa (gula) pada tikus yang diikuti oleh pemberian antosianin dari ubi jalar ungu (Ayamurasaki) $100 \mathrm{mg} / \mathrm{kg}$ menurunkan kadar glukosa darah 16,5\% setelah 30 menit disbandingkan perlakuan kontrol. Penelitian (Cahyono 2011) yang menyatakan bahwa terjadi penurunan kadar glukosa darah sekitar $19,5 \%$ pada penderita diabetes setelah diberi susu kedelai selama 5 hari berturut-turut dalam bentuk bubuk kedelai sebanyak $200 \mathrm{mg} / 200 \mathrm{cc}$ air.

Puding d'bingu dengan bahan utama ubi ungu dan kedelai dapat dimanfaatkan sebagai camilan sehat untuk penderita diabetes mellitus, karena pada pudding ini terdapat kandungan seperti antosianin, isoflavon, antioksidan dan serat yang dapat mengatur dan menurunkan kadar gula di dalam darah.

Menurut (Rosidah 2014), ubi jalar memiliki pigmen antosianin, dimana antosianin berperan sebagai anti diabetic dengan melindungi 
sel $\beta$ pancreas dari stress oksidatif akibat induksi glukosa (Ghosh and Konishi 2007), dan mampu menurunkan kadar glukosa darah dengan meningkatkan kerja reseptor insulin (Sabuluntika and Ayustaningwarno 2013). Disamping itu kacang kedelai mengandung Isoflavon yang memiliki efek untuk menghalangi penyerapan glukosa usus (Villages et al. 2008) dan bersifat sebagai antioksidan dan dapat meningkatkan sensitifitas insulin (Purwaningsih and Maryatun 2010).

Kandungan serat yang terdapat pada pudding d'bingu juga berperan dalam membantu menurunkan kadar glukosa darah pada penderita diabetes mellitus. Serat yang terdapat pada pudding d'bingu menyumbang sebanyak 33\% dari total kebutuhan sehari, sehingga kebutuhan serat per hari responden pada kelompok perlakuan dapat terpenuhi sesuai dengan kebutuhan.

Dari hasil penelitian yang dilakukan, pemberian pudding d'bingu dengan perbandingan $1: 1$ antara ubi ungu dan kedelai yang diberikan kepada penderita diabetes mellitus dapat menurunkan kadar glukosa darah dengan rata-rata penurunan $53.30 \mathrm{mg} / \mathrm{dl}$ selama 3 hari berturutturut.

\section{KESIMPULAN}

Pemberian puding d'bingu dengan perbandingan ubi ungu dan susu kedelai $1: 1$ sebanyak 2 kali sehari selama 3 hari menunjukkan ada pengaruh terhadap penurunan kadar glukosa darah.

\section{SARAN}

Penelitian ini perlu dilakukan lebih lanjut dengan waktu yang lebih lama agar rata-rata frekuensi dapat menggambarkan efek dari puding d'bingu itu sendiri.

\section{DAFTAR PUSTAKA}

Beckman, Jeremy. 2013. IDF Diabetes Atlas Sixth Edition. International Diabetes Federation.

Cahyono, Dwi Aris. 2011.Manfaat Susu Kedelai Sebagai Terapi Penurun Kadar Glukosa Darah Pada Klien Diabetes Mellitus
Fatimah, Restyana Noor. 2015. "Diabetes Melitus Tipe 2." J Majority 4 (5): 93. https://doi.org/10.14499/indonesianjphar m27iss2pp74.

Ghosh, Dilip, and Tetsuya Konishi. 2007. "Anthocyanins and Anthocyanin-Rich Extracts: Role in Diabetes and Eye Function" 16 (July 2006): 200-208.

Ginting, Erliana, Joko S Utomo, and Rahmi Yulifianti. 2015. "Potensi Ubijalar Ungu Sebagai Pangan Fungsional." Iptek Tanaman Pangan 6 (1).

Herliyanti, Yeni. 2016. "Hubungan Asupan Energi Dan Asupan Serat Dengan Kadar Glukosa Darah Pada Pasien Diabetes Melitus Rawat Jalan Di RSUP DR. M. Djammil Padang Tahun 2016." Universitas Andalas.

Isnaini, Nur.,Ratnasari. 2018. Faktor Resiko Mempengaruhi Kejadian Diabetes Mellitus Tipe Dua. Universitas Muhammadyah Purwokerto, Jawatengah. Jurnal Kesehatan dan Kebidanan Aisyiyah Vol. 14 No. 1.

Karta sapoetra. Marsetyo. 2000. Ilmu Gizi Korelasi gizi, Kesehatan, dan Produktivitas Kej. Jakarta: Rineka Cipta

Kedia, Nitil. 2011. "Treatment of Severe Diabetic Hypoglycemia with Glucagon: An Underutilized Therapeutic Approach." Diabetes, Metabolic Syndrome and Obesity: Targets and Therapy 4: 337-46. https://doi.org/10.2147/dmso.s20633.

Kesehatan, Badan Penelitian dan Pengembangan Kesehatan Kementerian. 2013. "Penyajian Pokok-Pokok Hasil Riset Kesehatan Dasar 2013.”

Muliani, Usdeka. 2013. "Asupan Zat-Zat Gizi Dan Kadar Gula Darah Penderita DM-Tipe 2 Di Poliklinik Penyakit Dalam RSUD Dr. H. Abdul Moeloek Provinsi Lampung." Jurnal Kesehatan IV (2): 325-32.

Paruntu, Olga Lieke. 2012. “Asupan Gizi Dengan Pengendalian Diabetes Pada Diabetisi Tipe II Rawat Jalan Di BLU Prof.Dr.R.D. Kandou Manado." Gizindo 4 (1): 327-37. 
Purwaningsih, Wahyu, and Maryatun. 2010. "Pengaruh Pemberian Suspensi Bubuk Kedelai Terhadap Penurunan Kadar Glukosa Darah Pada Tikus Putih Diabetes Melitus Yang Diinduksi Streptozotozin." Gaster 7 (2): 574-80.

Rosidah. 2014. "Potensi Ubi Jalar Sebagai Bahan Baku Industri Pangan." Teknobuga 1 (1): 44-52.

Sabuluntika, Novita, and Fitriyono Ayustaningwarno. 2013. "Kadar?Karoten, Antosianin, Isoflavon, Dan Aktivitas Antioksidan Pada Snack Bar Ubi Jalar Kedelai Hitam Sebagai Alternatif Makanan Selingan Penderita Diabetes Melitus TIPE 2" 2 (4): 689-95.

Santoso, Agus. 2011. "Serat Pangan (Dietary Fiber) Dan Manfaatnya Bagi Kesehatan.” Magistra 75: 35. https://doi.org/10.1108/eb050265.

Sinaga, Evi, and Yekti Wirawanni. 2012. "Pengaruh Pemberian Susu Kedelai Terhadap Kadar Glukosa Darah Puasa Pada Wanita Prediabetes." Journal of Nutrition College 1 (1): 312-21. https://doi.org/10.14710/jnc.v1i1.719.

Soelistijo, Soebagijo, Hermina Novida, Achmad Rudijanto, Pradana Soewondo, Ketut Suastika, Asman Manaf, Harsinen Sanusi, et al. 2015. Konsesus Pengelolaan Dan Pencegahan Diabetes Melitus Tipe2 Di Indonesia 2015. Perkeni.

https://www.google.com/url?sa=t\&sourc $\mathrm{e}=$ web\&rct=j\&url=https://pbperkeni.or.i d/wp-content/uploads/2019/01/4.-

Konsensus-Pengelolaan-dan-

Pencegahan-Diabetes-melitus-tipe-2-diIndonesia-PERKENI-

2015.pdf\&ved=2ahUKEwjy8KOs8cfoA hXCb30KHQb1Ck0QFjADegQIBhAB\& usg $=\mathrm{AOv}$.

Sudaryanto, Agus, Alis Noor Setiyadi, and Ayu Diah Frankilawati. 2014. "Hubungan Antara Pola Makan, Genetik Dan Kebiasaan Kerja Puskesmas Nusukan, Banjasari." Prosiding SNST, no. 3: 19-24.
Villages, Raquel, Yu-Tang Gao, Gong Yang, Hong-Lan Li, Tom A Elasy, Wei Zheng, and Xiao Ou Shu. 2008. "Legume and Soy Food Intake and the Incidence of Type 2 Diabetes in the Shanghai Women's Health Study." Am J Clin Nutr 87 (1): 162-67.

Wicaksono, Radio Putro. 2011. "FaktorFaktor Yang Berhubungan Dengan Kejadian Diabetes Melitus Tipe 2 (Studi Kasus Di Poliklinik Penyakit Dalam Rumah Sakit Dr. Kariadi.” Journal.Fk.Undip.Ac.Id 2: 1-22. http://eprints.undip.ac.id/37123/. 